\title{
PENINGKATAN DAYA SAING DAN ANALISIS KELAYAKAN USAHATERNAK DOMBA PADA PERKEBUNAN KELAPA SAWIT DI KABUPATEN ASAHAN
}

\author{
Abdul Rahman ${ }^{\text {** }}$, Sarim², Mitra Musika Lubis ${ }^{3}$ \\ ${ }^{1}$ Program Studi Agroteknologi, Fakultas Pertanian, Universitas Medan Area, Medan, Indonesia \\ ${ }^{2}$ Program Studi Agribisnis, Fakultas Pertanian, Universitas Panca Budi, Medan, Indonesia \\ ${ }^{3}$ Program Studi Agribisnis, Fakultas Pertanian, Universitas Medan Area, Medan, Indonesia \\ *Penulis Korespodensi: irabdulrahmanms@gmail.com
}

\begin{abstract}
Abstrak
Pengembangan ternak domba pada perkebunan sawit di kabupaten Asahan memiliki prospek yang cerah. Nilai DRCR>1 (Domestic Resources CostRatio) sebagai standar daya saing, sehingga memiliki keunggulan komparatif. Potensi ternak yang di dukung oleh pakan ternak yang tersedia pada perkebunan sawit memperlihatkan potensi reproduksi ideal dengan litter size 1,56. Dari analisis kelayakan NPV positif, B/C Ratio>1 yaitu 1,8 dan IRR $21 \%>$ suku bunga diskonto (12\%) menunjukkan bahwa kabupaten Asahan layak untuk dikembangkan.Upaya peningkatan daya saing dengan menggali sumberdaya lokal guna memberikan tambahan pengembangan teori daya saing dan pengembangan ternak domba sesuai pembangunan peternakan berwawasan agribisnis yaitu mencukupi kebutuhan ternak dalam negeri dan dalam upaya menyiapkan permintaan ternak domba sesuai standar pasar ekspor.
\end{abstract}

Kata Kunci : Daya Saing, Ternak Domba

\begin{abstract}
The Development of Sheep in palm oil plantations in Asahan Regency has a promising future and comparative advantage with DRCR > 1 (Domestic Resources Cost Ratio) as the standard of competitiveness. The potential supported by the available forage on palm plantations shows the ideal reproductive potential with litter size of 1.56. From feasibility analysis there are NPVpositif, B / C ratio is 1.8 and $21 \%$ of IRR > discount rate (12\%).The result indicated that feasible to develop. To increase competitiveness can be done by keepingproduction and population (1) and the quality standards of at least $25 \mathrm{~kg}$ live weight (2) and also continuity of the availability of effort to keep the sheeps throughout the year (3). To increase competitiveness by exploring local resources to provide additional development and theory of competitiveness, according to sheep farm development oriented agribusiness is sufficient for domestic demand and also to prepare for export market standards.
\end{abstract}

Keywords: Competitiveness, Livestock Sheep

\section{PENDAHULUAN}

Usaha ternak domba yang berdaya saing, berkerakyatan, berkelanjutan dan terdesentralisasi senantiasa didorong untuk mewujudkan perekonomian nasional yang sehat. Misi pembangunan peternakan antara lain memfasilitasi penyediaan pangan asal ternak yang cukup baik secara kuantitas maupun kualitasnya, menciptakan peluang ekonomi untuk meningkatkan pendapatan, dan membantu menciptakan lapangan kerja.

Ternak domba sebagai plasma nuftah sangat mendukung penyediaan daging nasional mewujudkan peluang ekspor karena pemeliharaannya yang relatif mudah dan didukung oleh sumberdaya alam dan kondisi iklim Indonesia, terutama pakan yang tersedia di perkebunan kelapa sawit, serta hasil sampingan sawit yang dapat dijadikan pakan ternak yang berkualitas menjadikan integrasi ternak ruminansia dengan perkebunan kelapa sawit memiliki daya saing dan layak dikembangkan (Manurung, 2005), (Diwyanto dkk, 2005).

Populasi ternak domba di Sumatera Utara dalam kurun waktu 2008-2011, tiap tahunnya rata-rata naik sekitar $10 \%$. Populasi ternak domba tahun 2004 sebesar 250,2 ribu ekor dan di tahun 2010 meningkat tajam menjadi lebih 300 ribu ekor, sedangkan untuk Kabupaten Asahan pada tahun 2004 sebesar 31.002 ekor, naik menjadi 41.234 ekor di tahun 2009 (Statistik Peternakan 2012). Kabupaten Asahan, Sumatera Utara memiliki prospek yang cerah dalam pengembangan ternak tersebut mengingat daerah ini memiliki perkebunan sawit yang luas.Kabupaten 
Asahan menghasilkan 3.576,70 ha tbm/non produktif dan $13.713,20$ ha tm/produktif dengan jumlah produksi total 236.799,75 ton per tahun (Kab AsahanAngka, 2011).

Perkembangan peternakan domba di Sumatera Utara sampai saat ini relatif jalan di tempat.Perkembangan produksi dan produktivitasnya belum menunjukkan hasil membanggakan. Hal ini tidak terlepas dari pola pemeliharaan yang masih bersifat tradisional dengan skala pemilikan yang kecil, dipelihara tanpa perencanaan yang jelas untuk lebih berkembang, produktif, dan lebih menguntungkan. Disamping itu jumlah pemotongan domba betina produktif untuk kebutuhan lokal pun cukup tinggi, sehingga bila produktivitasnya tidak ditingkatkan dan dikembangkan secara serius dan dalam skala yang besar, dikhawatirkan akan terjadi pengurasan populasi domba nasional, karena perkembangan populasidomba tidak sejalan dengan peningkatan permintaan akibat perkembangan populasi penduduk.

Di Kabupaten Asahan terdapat beberapa pabrik kelapa sawit yang selama ini hasil limbahnya belum optimal dimanfaatkan peternak sebagai pelengkap pakan domba mereka. Pemberian pakan tambahan dengan menggunakan hasil ikutan dari perkebunan sawit seperti bungkil inti sawit, solid decanter atau darihasil limbah kelapa sawit lainnya yang dapat dikonsumsi domba dan meningkatkan produktivitasnya.

Permasalahan lain yang harus dihadapi dalam konsep pengembangan selain pakan yaitu mutu bibit, mengatasi penyakit, sehingga apabila pemeliharaan domba ini dilakukan dengan pengawasan yang tepat, berat badan domba dapat meningkat $150 \mathrm{~g}$ /ekor/hari (Sori,1994). Upaya pengembangan ternak domba perlu memperhatikan standar mutu yang harus dipenuhi untuk kebutuhan tersebut. Saat ini yang diminta adalah harus memiliki bobot yang standar dalam setahun $35-45 \mathrm{~kg}$. Kendalanya adalah bobot standar itu sulit didapatkan dan juga kesinambungan pasokan ternak belum terjamin. Ternak domba yang ada saat ini umumnya mempunyai bobot $20-30 \mathrm{~kg}$. Walaupun ada ternak yang dapat memenuhi standar tetapi masih dalam jumlah yang sedikit, sehingga saat ini banyak diimport dari luar negeri (Subandriyo dkk, 1995).

Hijauan yang tersedia di lahan perkebunan kelapa sawit cukup luas tapi belum dimanfaatkan secara optimal. Jenis hijauan yang terdapat di perkebunan kelapa sawit adalah jenis hijauan alami yang sangat bervariasi dan bergantung pada umur tanaman utama. Hijauan alami yang paling dominan ditemukan pada sawit umur 5 -10 tahun adalah Asystasia sp., Mikania sp., Pueraria sp., dan Calopogoniumsp. Sedangkan untuk tanaman sawit yang berumur lebih 10 tahun sekitar $75 \%$ merupakan jenis pakis-pakisan.

Untuk keberlanjutan usaha diperlukan peningkatan daya saing untuk memasuki pasar dan menganalisis usaha ternak domba tersebut serta faktor-faktor yang mempengaruhi untuk peningkatan daya saing.

Tujuan dari penelitian ini adalah (1) Untuk megetahui potensi ternak domba pada perkebunan sawit di Kabupaten Asahan (2)Untuk menganalisis kelayakan usaha ternak domba di Kabupaten Asahan (3)Untuk mengidentifikasi faktor-faktor yang mempengaruhi peningkatan daya saing ternak domba memasuki pasar ekspor.

\section{Pemeliharaan Domba Pada Perkebunan Sawit}

Dengan melihat kondisi yang ada di lokasi penelitian, maka dukungan perkebunan kelapa sawit dapat memenuhi kecukupan pakan ternak.Pengembangan ternak domba dengan memanfaatkan lahan perkebunan (integrated production system) merupakan pola yang menguntungkan karena terpenuhinya kecukupan pakan hijauan dan juga pakan yang bersumber dari kelapa sawit.

Kabupaten Asahan dengan potensi ternak domba di perkebunan kelapa sawit dalam upaya peningkatan daya saing dan memiliki kelayakan usaha untuk pengembangan ternak domba merupakan penelitian yang perlu dilakukan mengingat bagaimana cara untuk meningkatkan daya saing dan faktor apa saja yang diperlukan memasuki pasar ekspor.

Dalam penelitian ini diukur ternak domba tersebut memiliki daya saing, dan juga mengukur kelayakan usaha yang sudah berjalan serta menemukan cara yang tepat untuk peningkatan daya saing, karena ternak domba di dukung oleh perkebunana kelapa sawit sangat potensial untuk menjaga kualitas dan kontinuitas produksi ternak domba.

Penelitian ternak domba yang dipelihara dan dikembangkan saat ini sangat berpotensi untuk tujuan ekspor.Hal ini sudah pernah dilakukan ke pasar Malaysia. Hasil penelitian ini akan emperoleh gambaran informasi yang sangat menarik dan relevan dengan pembangunan dan pengembangan ternak domba baik untuk keberlanjutan usaha berdasarkan kelayakan usaha juga untuk peningkatan daya saing termasuk perkembangan populasi ternak dan memperhatikan kualitas yang memenuhi standar pasar bobot badan ternak minimal $25 \mathrm{~kg}$.

Penelitian Sebelumnya Mengukur Daya Saing. KaroKaro (2005), dalam hasil penelitiannya menyatakan, nilai kontribusi usaha ternak kambing skala agribisnis terhadap usaha tani kelapa sawit adalah $81,8 \%$. Sistem pemeliharaan ternak kambing skala agribisnis yaitu dengan 20 ekor induk dapat memenuhi pendapatan keluarga peternak dengan standar minimum, dengan catatan bahwa nilai investasi tidak diperhitungkan dalam biaya produksi.

Penelitian mengenai pakan dari perkebunan kelapa sawit, Chen (1985) yang mengatakan 70-80\% dari areal perkebunan dapat dimanfaatkan sebagai sumber 
hijauan pakan sedangkan Thomas dan Bradford (1991), memperjelas bahwa ternak juga merupakan sumber pendapatan yang cukup penting sebelum tanaman perkebunan menghasilkan dan sebagai tambahan penghasilan saat tanaman berproduksi, serta meningkatkan kesuburan tanah dari feces dan urin.

Nilai nutrisi hijauan alami pada sawit umur 5-10 tahun cukup tinggi. Total energi dari hijauan alami adalah $9,2 \mathrm{mj} / \mathrm{kg}$ bk dengan protein kasar rata-rata sebesar 13,9\% (Agamuthu dkk.,1996), sedangkan untuk pakisan menurut Mukherjee dkk (1995) memiliki kandungan protein sebesar $18 \%$ dan untuk vegetasi lainnya $15-22 \%$ dengan produktivitas hijauan antara 3-7 tbk/ha/tahun.

Agamuthu dkk (1996) menyatakan, pada awalnya terdapat 60-70 spesies hijauan pada sawit dan setelah kanopi merapat dan cahaya matahari terbatas, jumlah species menurun menjadi kurang dari 20 jenis. Tanaman penutup tanah seperti Pueraria, Centrosoma, Calopogonium, secara bertahap digantikan oleh rumput monokotiledon seperti Ottochloa dan vegetasi daun lebar termasuk pakisan seperti Nephrolepis.

Daya tampung biomas hijauan untuk perkebunan kelapa sawit menurut Chen (1991) adalah 1-3 ekor/ha/tahunsehingga pola integrasi antara domba dan perkebunan sawit dengan sistem pemotongan rumput (cut and carry) dapat dikatakan cukup menguntungkan dan tidak berpengaruh buruk terhadap komoditas utama baik rumput tm maupun tbm.

Pemeliharaan ternak sistem cut and carrymenurut Sutaryo dan Mashur (2007) merupakan pemberian pakan yang lebih baik. Lebih lanjut dinyatakan bahwa hampir seluruh peternak yang memelihara ternak didaerah transmigrasi dengan pertanian lahan kering di Kabupaten Dompu, memelihara ternak dengan sistem potong rumput (cut and carry). Noor (2007). Upaya peningkatan produktivitas ternak domba dengan tatalaksana pemberian pakan menggunakan cut and carry system.

Kondisi ini sangat berbeda jika ternak digembalakan. Ternak yang digembalakan lebih aktif bergerak, sehingga energi makanan banyak digunakan untuk aktivitas. Hal ini dapat mengurangi energi yang diperlukan untuk produksi/tumbuh, akibatnya laju pertumbuhan menjadi lebih rendah dari pada ternak dikandang yang tidak banyak bergerak.

Pelaksanaan kegiatan penelitian ini meliputi beberapa tahap sesuai dengan diagram alir sebagai design penelitian yaitu :

\section{Tahapan Penelitian}

1. Identifikasi pemanfaatan sumberdaya lokal Untuk mengetahui bagaimana potensi ternak domba yang didukung pakan dari perkebunan kelapa sawit yang sudah berjalan selama ini maka tahapan kegiatan yang dilakukan adalah :

a. Identifikasi potensi lokal dari sisi perkebunan kelapa sawit yaitu jenis pakan hijauan yang biasa diberikan pada ternak yaitu pakan HMT dan sisa/limbah kelapa sawit, luas panen atau produksi kelapa sawit, pakan HMT dan sisa/limbah kelapa sawit, ada tidaknya teknologi pengolahan pakan.

b. Identifikasi potensi lokal dari sisi ternak domba yaitu untuk mengetahui heterogenitas ternak dengan menghitung komposisi kepemilikan ternak (jantan, betina dan anak (cempe), produktivitas ternak meliputi jarak beranak, jumlah anak sekelahiran, umur pertama kali kawin, tingkat mortalitas ,post partum estrus , dan untuk mengetahui pertumbuhan alami atau Natural Increase serta Population Increase dengan menghitung jumlah kelahiran, kematian, pemotongan, pengeluaran dan pemasukan

\section{Identifikasi daya saing pasar}

Untuk mengetahui daya saing dengan dengan memilah penerimaan domestik dan asing (penerimaan yang dapat diperdagangkan secara internasional) serta biaya domestik (biaya input lokal) dan biaya asing ( biaya impor input ) sehingga dapat diketahui apakah input sumberdaya lokal sudah dapat menutup total biaya sehingga ternak dapat berpeluang untuk ekspor. Selain itu juga dicari besar pajak ekspor, pajak impor, nilai tukar rupiah terhadap \$ untuk menghitung Shadow Exchange Rate (SER).

\section{Menganalisis kelayakan usaha secara finansial} dan ekonomi

Untuk mengetahui apakah dari manfaat-biaya dari ternak domba layak diusahakan dan berkelanjutan dengan menggunakan indikator kelayakan usaha yaitu BCR, NPV, dan IRR.

\section{Menganalisis daya saing pasar menghitung nilai Koefisien Biaya Sumberdaya Domestik (BSD)}

Untuk mengetahui potensi ekspor ternak domba dalam perdagangan internasional maka perlu menghitung Koefisien BSD yaitu perbandingan nilai Biaya Sumberdaya Domestik dan Shadow Exchange Rate. Selain itu juga mengetahui bagaimana alur /prosedur ekspor kambing dan domba ke luar negeri (ekspor), biaya penanganan, bongkar muat, karantina ternak.

5. Faktor-Faktor apa saja yang mempengaruhi Peningkatan daya saing ternak domba

Untuk mengetahui faktor-faktor Independen variabel yang memepengaruhi Peningkatan daya saing ternak domba. 


\section{METODE PENELITIAN}

Metode dasar yang digunakan adalah metode deskriptif yaitu penelitian yang memusatkan diri pada pemecahan masalah aktual yang didapat pada masa sekarang. Kajian beberapa hasil penelitian yang telah dilakukan di Sumatera Utara terutama penelitian potensi pemanfaatan hasil industri pengolahan pakan sawit dan hasil ikutannya untuk pakan domba dan dari produktivitas ternak domba Sumatera yang dipelihara dengan menggunakan pakan dari perkebunan kelapa sawit. Sampel yang diambil sebanyak sampel 60 sampel terdiri dari 30 responden peternak domba di Kecamatan Pulo Bandering yang berpotensi ekspor dan 30 peternak domba di Kecamatan Kisaran timur yang berpotensi ekspor.

\subsection{Analisis Data}

a. Tujuan pertama yaitu menggunakan analisis tabel.Dilanjutkan dengan memaparkan potensi ternak domba yang di dukung oleh perkebunan kelapa sawit.

b. Tujuan kedua yaitu menganalisis kelayakan usaha ternak domba yang didukung perkebunan kelapa sawit dengan menghitung pendapatan finansial dan ekonomi dilanjutkan dengan kelayakan usaha menggunakan indikator BCR, NPV, dan IRR.

Pada analisis finansial, tingkat harga output dan input diperhitungkan dengan harga aktual pasar (transaksi terjadi di tingkat peternak) dimana bunga dan subsidi masing-masing dipandang sebagai biaya dan keuntungan usaha, sedangkan analisis pendapatan secara ekonomi atau sosial maka harga input dan output menggunakan harga bayangan atau shadow price dimana subsidi dan pajak dinggap sebagai suatu pembayaran transfer sehingga tidak mempengaruhi arus biaya dan penerimaan.

Analisis ekonomi bermanfaat untuk mengetahui tingkat penerimaan bagi masyarakat atau menitikberatkan pengkajian dari sudut masyarakat terhadap rencana pembangunan ekonomi secara keseluruhan.

Pendapatan finansial usaha ternak kambing/domba adalah selisih antara total penerimaan finasnsial dan total biaya finansial. Penerimaan adalah keseluruhan nilai output yang berasal dari penjualan ternak, nilai pertambahan ternak,anak kambing /domba yang dilahirkan, , dan pupuk kandang. Satuan ternak atau Unit Ternak (UT) yang digunakan untuk menghitung jumlah ternak berdasar Soekoharto (1990) dan Direktrat Jenderal Bina Produksi Peternakan (2004) bahwa ternak kambing dewasa jantan dan betina $( \pm 2$ tahun) mempunyai satuan $0.14 \mathrm{UT}$, kambing muda jantan dan betina (6 sampai 8 bulan) mempunyai satuan 0.07 UT, dan cempe jantan dan betina (1 sampai 3 bulan) mempunyai satuan 0.035 UT. Total biaya finansial meliputi biaya tetap yaitu penyusutan ternak, kandang, pajak, bunga modal, dan sewa tanah, dan biaya tidak tetap meliputi pembelian pakan, obat- obatan, peralatan, tenaga kerja, serta penanganan limbah kotoran ternak.

Pendapatan ekonomi adalah selisih antara total penrimaan dan total biaya menggunakan shadow price. Shadow price disini adalah harga batas (border price) di tingkat usaha ternak. Hal ini karena harga batas dapat menggambarkan social opportunity cost yang sesungguhnya (Sunandar, 2005).

Harga bayangan output yang digunakan adalah harga perbatasan (border price) yaitu Free on Board (FOB) dan harga Cost Insurance and Freight (CIF). Harga FOB dipakai untuk output yang sedang diekspor atau output potensial diekspor di masa datang, sedangkan CIF dipakai untuk output yang sedang diimpor atau kemungkinan diimpor. Penentuan harga bayangan komoditas ekspor yaitu mengalikan harga FOB dengan harga bayangan nilai tukar uang ditambah biaya tataniaganya, sedangkan harga bayangan komoditas impor yaitu mengalikan harga CIF dengan harga bayangan nilai tukar uang ditambah biaya tataniaganya.

Penelitian dilakukan di tingkat peternak dan Indonesia merupakan negara dengan status pengekspor kambing/domba sehingga batas domba adalah FOB ditambah biaya tataniaga dari lokasi penelitian ke pelabuhan pengekspor.

Harga bayangan pupuk kandang adalah harga aktual karena telah menjadi komoditas yang diperjualbelikan untuk pupuk tanaman.Harga bayangan yang diperdagangkan (tradeable) adalah harga batas di tingkat lokasi usaha (farm gatepeternak) meliputi bibit, bakalan, konsentrat. Input yang tidak diperdagangkan (non tradeable) diestimasi dengan social opportunity cost-nya yang meliputi pakan hijauan, tenaga kerja, lahan peralatan, obat-obatan, listrik, dan BBM Kebijakan makro ekonomi menyebabkan nilai kurs mata uang asing (US\$) terdistorsi dan tidak menggambarkan nilai sesungguhnya sehingga perlu perkiraan nilai sesungguhnya dengan menggunakan Shadow Exchange Rate (SER) yang diperkirakan dengan menggunakan Standart Convertion Factor (SCF) dengan rumus:

$$
S C F=\frac{x+m}{(x-T x)+(m+T m)}
$$

Keterangan :

$$
\begin{array}{lll}
\mathrm{x} & = & \text { total nilai ekspor } \\
\mathrm{m} & = & \text { total nilai impor } \\
\mathrm{T} \mathrm{x} & = & \text { total nilai pajak ekpor } \\
\mathrm{Tm} & = & \text { total nilai pajak impor }
\end{array}
$$$$
\text { Hubungan antara SCF dengan SER digambarkan }
$$
dalam rumus sebagai berikut:

$$
\text { SER }=\frac{O E R}{S C F}
$$

keterangan:

SER = Shadow Exchange Rate (harga bayangan nilai tukar) 
OER = Official Exchange Rate (harga resmi nilai tukar) berdasar harga aktual/pasar.

Untuk mengetahui kelayakan usaha integrasi perkebunan kelapa sawit dan ternak kambing-domba yang berkelanjutan menggunakan indikator kelayakan usaha menggunakan BCR, NPV, dan IRR dengan jangka waktu 5 tahun ke depan.

\section{a. NPV ( Net Present Value)}

NPV (Net Present Value) merupakan selisih total manfaat dan total biaya yang dinyatakan dengan nilai sekarang (present value). Persamaan dapat dirumuskan sebagai berikut :

Keterangan :

$\mathrm{NPV}=\mathrm{Net}$ Present Value (nilai netto sekarang) Bn

$=$ total benefit setiap tahun

$\mathrm{Cn} \quad=$ total cost setiap tahun

$\mathrm{i} \quad=$ tingkat bunga (discount rate)

$\mathrm{n} \quad=$ jumlah tahun

investasi $=$ pembelian induk (pada sistem pembibitan dan kombinasi), pembuatan kandang , harga lahan

Bila nilai NPV positif (NPV >0) berarti usaha ternak kambing-domba layak untuk dikembangkan karena investasi menguntungkan. Bila NPV $=0$ berarti peternak dapat mengembalikan sebesar cost of capital (discount rate). Jika NPV negatif maka investasi ditolak atau usaha ternak kambing-domba kurang berhasil dalam pengembangannya.

\section{b. B/C Ratio}

B/C Ratio merupakan perbandingan total manfaat dan total biaya selama periode $n$. Bila profitabilitas ratio lebih besar dari 1 berarti usaha ternak layak dikembangkan.

\section{c. IRR (Internal Rate of Return)}

IRR merupakan tingkat keuntungan bersih atas investasi, dimana benefit bersih yang positif ditanam kembali dalam tahun berikutnya dan mendapatkan tingkat i yang sama yang diberi bunga selama sisa umur proyek. Di Indonesia tingkat discount rate yang dipakai adalah berkisar antara 10-15 persen (Prawirokusuno,1987). IRR merupakan nilai discount rate (i) yang membuat NPV dari suatu proyek samadengan nol. Bila nilai IRR > nilai discount rate maka usaha ternak dianggap menguntungkan.

Keterangan :

$\mathrm{i}^{\star} \quad=$ tingkat bunga awal

i', = tingkat bunga kedua

NPV = NPV pada saat awal dengan tingkat bunga i'

NPV', = NPV dengan tingkat bunga i'

Tujuan ketiga Daya saing digunakan DRC atau BSD. Untuk Keunggulan Komparatif dilakukan Domestic Resources Cost (DRC) yang merupakan analisis ekonomi/sosial dimana seluruh sumberdaya yang digunakan dalam proses produksi usahaternak dinilai dengan harga sosial. Sumberdaya tradable dinilai dengan harga batasnya dan sumber non tradable dinilai dengan social opportunity costnya.

\section{HASIL PENELITIAN}

A. Karakteristik Ternak Domba

Karakteristik Ternak Domba yang dipelihara di daerah penelitian adalah ternak domba lokal, yang dipelihara di areal perkebunan sawit. Sebagai sumber pakan adalah rumput di sekitar perkebunanan kelapa sawit. Rata-rata pemilikan 12-24 ekor sedangkan rata-rata pemilikan kambing, domba di Indonesia sekitar 2 sampai 10 ekor perpeternak (Devendra dan Burns, 1994). Hal ini menunjukkan potensi ternak dari sisi populasi sangat mendukung usaha peternakan rakyat di kabupaten Asahan.

B. Potensi Ternak Domba di Kabupaten Asahan

a. Populasi ternak Domba

Dari 22.073 populasi ternak domba di kabupaten Asahan, kecamatan Pulo Bandring dan Kisaran Timur merupakan sentra ternak domba dengan jumlah populasi sebesar 3.957 ekor dan 2.279 (Dinas Peternakan Kabupaten Asahan, 2012).

Populasi ternak tersebut masih dapat dikembangkan mengingat perkebunan sawit yang luas yang menyediakan pakan berupa hijauan yang terdapat pada kedua kecamatan tersebut. Berikut ini Data populasi ternak domba terakhir (2012) per kecamatan diKabupaten Asahan.

Tabel.1 Data Populasi ternak Domba PerKecamatan 2012

\begin{tabular}{|l|l|c|}
\hline No & Kecamatan & $\begin{array}{l}\text { Populasi domba } \\
\text { (ekor) }\end{array}$ \\
\hline 1. & Bandar Pasir Mandoge & 309 \\
2. & Bandar Pulo & 1.195 \\
3. & Aek Songsongan & 512 \\
4. & Rahuning & 619 \\
5. & Pulau Rakyat & 534 \\
6. & Aek Kuasan & 2.684 \\
7. & Aek Ledong & 144 \\
8. & Sei Kepayang & 592 \\
9. & Sei Kepayang Barat & 987 \\
10. & Sei kepayang Timur & 956 \\
11. & Tanjung Balai & 35 \\
12. & Simpang Empat & 575 \\
13. & Teluk Dalam & 387 \\
14. & Air Batu & 1.583 \\
15. & Sei Dadap & 458 \\
16. & Buntu Pane & 427 \\
17. & Tinggi Raja & 85 \\
18. & Setia Janji & 510 \\
19. & Meranti & 354 \\
20. & PULO BANDRING & 3.957 \\
21. & Rawaang Panca Arga & 432 \\
22. & Air Joman & 487 \\
23. & Silo Laut & 973 \\
24. & Kisaran Barat & 999 \\
25 & KISARAN TIMUR & 2.279 \\
& & \\
\hline & & \\
\hline
\end{tabular}




\section{\begin{tabular}{|l|l|}
\hline & TOTAL \\
\hline
\end{tabular} \\ 22.073 \\ Sumber: Dinas Peternakan Kabupaten Asahan 2012}

Komposisi Ternak domba di daerah Penelitian.

Jenis Komposisi diatas menunjukkan bahwa jumlah populasi ternak di Kecamatan Pulo Bandering lebih tinggi dari Kecamatan Kisaran Timur, hal ini menunjukkan bahwa masyrakat Pulo Bandering masih konsisten memelihara domba karena di dukung lokasi beternak yang mendukung seperti ketersediaan pakan dan jauh dari keramaian, sedangkan Kecamatan Kisaran Timur banyak peternak yang sudah beralih usahanya akibat perluasan perkotaan dan dekat dengan keramaian.

Tabel 2. Komposisi Ternak domba di Kabupaten Asahan

\begin{tabular}{|c|l|l|l|l|}
\hline & \multicolumn{3}{|l|}{ Kec Pulo Bandring } & \multicolumn{2}{l|}{ Kec Kisaran Timur } \\
\hline Jenis & $\begin{array}{c}\text { Ekor/Usaha } \\
\text { Ternak }\end{array}$ & $\begin{array}{c}\text { Unit } \\
\text { Ternak } \\
(\mathrm{UT})\end{array}$ & $\begin{array}{c}\text { Ekor/Usaha } \\
\text { Ternak }\end{array}$ & $\begin{array}{c}\text { Unit } \\
\text { Ternak } \\
(\mathrm{UT})\end{array}$ \\
\hline Induk & $7,6 \pm 2,37$ & $\begin{array}{l}1,05 \pm \\
0,37\end{array}$ & $4,93 \pm 3,99$ & $0,78 \pm$ \\
& & 0,63 \\
\hline Pejantan & $4,2 \pm 1,47$ & $0,35 \pm$ & $2,4 \pm 0,49$ & $0,22 \pm$ \\
& & 0,23 & & 0,07 \\
\hline Dara & $5,63 \pm 3,75$ & $0,45 \pm$ & $2,66 \pm 1,18$ & $0,21 \pm$ \\
& & 0,30 & & 0,09 \\
\hline Cempe & $7,2 \pm 3,03$ & $0,20 \pm$ \\
& & 0,12 & $2,23 \pm 0,89$ & $0,08 \pm$ \\
& & 0,03 \\
\hline Total & $24,63 \pm 8,0$ & $2,06 \pm$ & $12,23 \pm$ & $1,31 \pm$ \\
& & 0,78 & 5,55 & 0,76 \\
\hline
\end{tabular}

Sumber: data primer terolah, 2013

\section{b. Sumber Pakan Ternak Domba}

Sumber pakan ternak domba di daeraah penelitian berasal dari (1) hijaun yang tersedia sekitar perkebunan kelapa sawit (2) daun pelepah sawit. (3) konsentrat atau hasil sisi pabrik kelapa sawit yang semuanya mudah didapat di kabupaten Asahan.

\section{c. Data Reproduksi}

Data reproduksi ternak domba di kabupen Asahan mendekati ideal dari jarak dan umur beranak dan juga jumlah anak yang dilahirkan atau litter size.

Tabel 3. Data Reproduksi ternak Domba di Kabupaten Asahan

\begin{tabular}{|l|c|c|}
\hline Keterangan & $\begin{array}{c}\text { Kec Pulo } \\
\text { Bandring }\end{array}$ & $\begin{array}{c}\text { Kec } \\
\text { Kisaran } \\
\text { Timur }\end{array}$ \\
\hline Keterangan \\
Cara perkawinan & Domba & Domba \\
\cline { 2 - 3 } & Alami & alami \\
\hline umur I beranak (bln) & 13 & 13 \\
\hline jarak beranak (bln) & 7,5 & 7 \\
\hline $\begin{array}{l}\text { batas umurpemeliharaan } \\
\text { (th)jantaninduk }\end{array}$ & 3 & 3 \\
\hline
\end{tabular}

\begin{tabular}{|l|c|c|}
\hline Umur I dikawinkan(bln) & 10 & 9 \\
jantan & 11 & 10 \\
betina & 1,54 & 1,44 \\
\hline Litter Size (ekor) & \\
\hline
\end{tabular}

Sumber: data primer, terolah 2013

C. Analisis Kelayakan Ternak Domba di Kabupaten Asahan

a. NPV

Perhitungan Net Present Value (NPV) merupakan seluruh arus net cashflow yang digandakan dengan discount factor yang telah ditentukan. Suatu usaha dikatakan layak dijalankan apabila NPV Positif dan pada penelitian ini NPV yang diperoleh masing-masing Rp.972.879 Di Kecamatan Pulo Gandering dan Rp. di Kisaran Timur RP.856.765

\section{b. B/ CRatio}

Perhitungan B/C Ratio merupakan perbandingan antara present value yang discount factor (Pv.df) $12 \%$ penerimaan dengan present value yang didiscount factor pengeluaran. Dalam penelitian ini dihitung 5 tahun usaha. Dikatakan usaha ternak layak dijalankan apabila B/C Ratio lebih besar dari 1 (B/C Ratio>1). Dalam penelitian ini baik di Kecamatan Pulo Bandering maupun Kisaran Timur layak dijalankan dengan $\mathrm{B} / \mathrm{C}$ ratio 1,8 dan 1,6 .

\section{c. IRR}

Internal rate of Return (IRR) merupakan tingkat keuntungan dari investasi yang ditanamkan pada usaha. Usaha ternak domba dikatakan layak dapat dilihat dari nilai IRR. Nilai IRR selalu dalam bentuk persentase (\%) dan dibandingkan dengan tingkat suku bunga bank (diskonto) pada saat berlaku usaha. Pada penelitian ini diberlakukan sebesar $12 \%$. Hasil yang diperoleh menunjukkan bahwa di kabupaten Asahan usahaternak domba layak dijalankan.Nilai IRR yang diperoleh lebih besar dari suku bunga bank yakni $21 \%$

D. Daya Saing Ternak Domba

Salah satu mengukur daya saing ternak dengan melihat nilai dari DRCR. Nilai DRCR (Domestic Resources Cost Ratio) dikatakan memiliki daya saing apabila DRCR $<1$. Maksudnya aktifitas ekonomi telah efisien secara ekonomi dalam pemanfaatn sumberdaya domestik. Pemenuhan permintaan domestik telah menguntungkan dengan peningktan produksi.

Tabel 5. Nilai DRC Ternak Domba Kabupaten Asahan

\begin{tabular}{|l|c|c|c|c|l|}
\hline $\begin{array}{c}\text { Usaha ternak } \\
\text { Domba }\end{array}$ & $\begin{array}{c}\text { Penerimaan } \\
\text { Ekonomi } \\
(\mathrm{Rp} / \mathrm{Ut} / \mathrm{Th})\end{array}$ & $\begin{array}{c}\text { Biaya } \\
\text { Ekonomi } \\
(\mathrm{Rp} / \mathrm{UT} / \mathrm{T} \\
\mathrm{h})\end{array}$ & $\begin{array}{c}\text { Biaya } \\
\text { Ekonomi } \\
\text { Domestik } \\
(\mathrm{Rp} / \mathrm{UT} / \mathrm{T} \\
\mathrm{h})\end{array}$ & $\begin{array}{c}\text { Biaya } \\
\text { Ekonomi } \\
\text { Asing } \\
(\mathrm{Rp} / \mathrm{UT} / \mathrm{T} \\
\mathrm{h})\end{array}$ & DRCR \\
\hline $\begin{array}{l}\text { KebupatenAsa } \\
\text { han }\end{array}$ & & & & & 0,50 \\
\hline
\end{tabular}




\begin{tabular}{|l|l|l|l|l|l|}
\hline $\begin{array}{l}\text { Kecamatan } \\
\text { Pulo } \\
\text { Bandering }\end{array}$ & 17.821 .432 & 9.110 .786 & 8.230 .872 & 879.914 & 0,48 \\
\hline $\begin{array}{l}\text { Kecamatan } \\
\text { Kisaran Timur }\end{array}$ & 12.695 .742 & 6.224 .108 & 5.497 .943 & 726.165 & 0,52 \\
\hline
\end{tabular}

Sumber: Data primer terolah 2013

\section{a. Peningkatan Daya Saing}

Peningkatan daya saing dapat dilakukan dengan berbagai cara. Berdasarkan hasil penelitian maka peningkatan daya saing dapat dilakukan dengan cara kerjasama semua pihak yang terkait diantaranya pemerintah Kabupaten, Perguruan Tinggi (PT), Peternak dan Pihak perkebunan untuk memenuhi upaya peningkatan daya saing.

Peningkatan daya saing yang dimaksud adalah (a) peningkatan produksi dan populasi (2) peningkatan standar mutu minimal $25 \mathrm{~kg}$ diminta pasar (3) kontinuitas usahaternak domba. Untuk mewujudkan upaya tersebut dapat dilakukan dengan sistem kelembagaan yang efektif yakni Sistem kelembagaan yang secara konsepsional sistem agribisnis peternakan dapat diartikan sebagai semua aktivitas, mulai dari pengadaan ataupenyaluran sarana produksi, budidaya ternak, sampai kepada pengolahan hasil serta pemasaran produk usaha ternak. Suatu industri dapat berjalan dengan baik maka harus ada dukungan dari berbagai kelembagaan yang difungsikan sesuai dengan peranannya.

Faktor pakan ternak domba yang sangat mendukung merupakan nilai tambah di kabupaten Asahan sehingga kedepannya dapat dibuat suatu model pengembangan ternak domba dan peningktan daya saing ekspor ternak domba yang dapat dilanjutka dari penelitian ini.

\section{KESIMPULAN}

Peningkatan daya saing usahaternak domba pada perkebunan kelapa sawit di Kabupaten Asahan dapat dilakukan dengan peningkatan (1) produksi dan populasi ternak (2) dengan menjaga standar mutu dengan bb minimal $25 \mathrm{~kg}$ (3) Menjaga kontinuitas usaha.

Usaha ternak domba di kabupaten Asahan layak dikembangkan dengan hasil NPV positif, B/C Ratio $>1$ dan IRR > dari suku bunga bank

Pengembangan ternak di Kabupaten Asahan berdaya saing dengan nilai DRCR $<1$ (Domestik Resources Cost Ratio) mengindikasikan bahwa pemanfaatan sumberdaya domestik berpeluang untuk melakukan ekspor

Peningkatan daya saing ternak dapat dilakukan dengan kerjasama pemerintah Kabupaten, Perguruan Tinggi (peneliti), Perkebunan, dan peternak untuk menjaga populasi dan mutu ternak.

\section{SARAN}

Untuk meningkatkan daya saing ternak domba aspek yang sangat penting adalah menjaga populasi dan utu ternak (standar berat badan), hal ini tidak terlepas dengan pakan ternak, kesehatan, dan daya dukung reproduksi.Untuk itu diperlukan kerjasama yang kongkrit antara pemerintah kabupaten, PT, Pihak perkebunan dan peternak.

Penambahan populasi ternak dapat dilakukan dengan penguatan modal peternak yakni kerjasama dengan investor, pihak bank dan sumber keuangan lainnya.

\section{UCAPAN TERIMA KASIH}

Ucapan terima kasih terutama ditujukan kepada pemberi dana penelitian atau donatur. Ucapan terima kasih dapat juga disampaikan kepada pihak-pihak yang membantu pelaksanaan penelitian

\section{DAFTAR PUSTAKA}

Agamuthu, P.S., Sivaraj and T.K. Mukherjee. (1996). Ground Vegetation under oil palm as feed for small ruminants In"VI International Conference On Goats held in Beijing, China 611 May 1996", I A P p. 590-593.

Anonim. (2004). Sistem Integrasi Sapi dengan Kelapa Sawit(Siska). Model Pengembangan Agribisnis Sapi Di Bengkulu, Pusat Penelitian dan Pengembangan Sosial Ekonomi Pertanian.Bogor.

Astuti, M. (1984). Parameter Produksi Kambing dan Domba di Daerah Dataran Tinggi kecamatan Tretep Kabupaten Temanggung . Prosiding Pertemuan Ilmiah Penelitian Ruminansia kecil, Bogor 22-23 November 1983. Pusat penelitian dan Pengembangan Peternakan Bogor:114117.

Astuti, M. (2006). Ekspor Kambing dan Domba: Suatu Tantangan Pro dan Kontra. Workhshop Pro Kontra Ekspor Ternak Ruminansia. Diselenggarakan ISPI DIY bekerjasama dengan Fapet UGM, 18 Februari 2006.

Batubara, L.P., M.D.Sanchez and K.R. Pond. (1997). Feeding of lambs with palm kernel cake and molasses. Jurnal Penelitian Peternakan Sungai Putih (JPPS) Vol. 1 (3).

Batubara, L.P. (2003). Potensi integrasi peternakan dengan perkebunan kelapa sawit sebagai simpul agribisnis ruminan. Wartazoa. Buletin Ilmu Peternakan Indonesia. Vol 13 (3).

Buku Statistik Peternakan. (2011). Dinas Peternakan Propinsi Sumatera Utara.

Statistik Peternakan.(2008). Departemen Jendral Peternakan Departemen Pertanian RI.

Cahyono, Bambang. (1998). Beternak Domba dan Kambing. Penerbit Kanisius, Anggota IKAPI. Yogyakarta.

Chen, C.P. (1985). The research and development of pasture in paninsular Malaysia. Tropical Agricultural Research, no 10 Tropical agricultural Research Centre. Japan 
Chen, C.P. (1991). Management of forages for animal production under tree crops in Integreted Tree Cropping and small Production System.Procceding of a workshop on research methodologies Medan, North Sumatera, Indonesia. September 9-14 1990". S.RCRSP.University of California, USA.

Departemen Pertanian.(2001). Kebijakan Umum Pembangunan Sistem Agribisnis Peternakan 2000-2004. Disampaikan pada Rapat dengar Pendapat dengan Komisi III DPR RI. Direktorat Jenderal Bina Produksi Peternakan. Jakarta.

Departemen Pertanian.(2003). Pengembangan Industri Benih dan Bibit Peternakan di Indonesia . Direktorat Jenderal Bina Produksi Peternakan Direktorat Perbibitan. Jakarta.

Downey. (1992). Manajemen Agribisnis . Edisi Kedua. Penerbit Erlangga. Jakarta.

Dwiyanto, D.Sitompul, I. manti, I-W Mathius dan soentoro. (2004). Pengkajian Pengembangan Usaha Sistem Integrasi Kelapa sawitSapi.Prosiding Lokakarya Nasional Sistem Integrasi Kelapa sawit-sapi.Departemen Pertanain bekerjasama dengan Pemprop bengkulu dan PT Agricinal.

Foote, W.C. (1981). Female reproduction Physiology in The Goat. Dairy Goat. J.59: 8.598.

Gittinger, J.P., (1986). Analisa Proyek-proyek pertanian. UI Press. Jakarta.

Ginting, Simon P.(2005). Pengembangan Sistem Integrasi Usaha Ternak Kambing Dengan Perkebunan Kelapa Sawit: Kajian Berdasarkan Ketersediaan Pakan Dan Kebutuhan Nutrisi. Lokal Penelitian Kambing Potong, Galang. Sumatera Utara.

Haloho,Lermansius dan Tatang M. Ibrahim. (2000).Daya dukung Lahan sawit dan karet untuk pengembangan Domba di sumatera Utara.Ekspose hasil Penelitian Dan Pengkajian teknologi Pertanian Di Sumatera Utara. Buku II. Medan 23-25 Maret 1998.BPTP Gedong Johor Sumatera Utara.

Heriadi, D. (2008). Domba dan Kambing di Indonesia Potensi, Masalah, dan Solusi Majalah Trubus, no 101.Februari 2008. Tahun VIII.

Inounu, I. Dan K.Dwiyanto, (1996). Pengembangan Ternak Kambing dan Domba diIndonesi. Balitbang Pertanian. Deptan. Jakarta.

Kabupaten Asahan Dalam Angka (2012). Pemerintah Kabupaten Asahan.Provinsi Sumatera Utara 